\title{
Experimental Evaluation of Sugar Cane Bagasse Storage in Bales System
}

\author{
J. Lois-Correa* ${ }^{* 1}$ A. Flores-Vela ${ }^{2}$, D. Ortega-Grimaldo ${ }^{3}$, J. Berman-Delgado ${ }^{4}$ \\ ${ }^{1,2,3,4}$ Research Center of Applied Science and Advanced Technology \\ (CICATA-IPN), National Polytechnic Institute, Unit Altamira, \\ km.14.5 Road Tampico-Industrial Port Altamira, C.P. 89600 \\ Altamira, Tamaulipas, México \\ *joralois@yahoo.com
}

\begin{abstract}
An experimental evaluation was carried out on three bagasse storage piles with the following characteristics: wet baled raw bagasse, wet baled depithed bagasse and pre-dried baled depithed bagasse. In each of these formerly mentioned alternatives, the storage time influence was analyzed on temperature profile, humidity behavior, granulometry and morphology, with and without mechanical treatment, solubility in hot water, $\mathrm{NaOH}$ and alcoholbenzene extractives. In the same way, the behavior of brightness in mechanical pulps produced from stored bagasse was studied. Storage losses were calculated for each alternative on the basis of obtained results and it was demonstrated that pre-dried bagasse as compared with wet bagasse storage, yields lower losses and better conservation of its characteristics.
\end{abstract}

Keywords: Bagasse, depithing, storage, bales system, cellulose, pentosans, lignin, losses.

\section{RESUMEN}

Una evaluación experimental se llevó a cabo en tres pilas de almacenamiento de bagazo con las siguientes características: bagazo integral empacado en húmedo, bagazo desmedulado empacado en húmedo y bagazo desmedulado empacado presecado. En cada una de las alternativas anteriormente mencionadas, se analizó la influencia del tiempo de almacenamiento sobre el perfil de temperatura, el comportamiento de la humedad, la granulometría y morfología, con y sin tratamiento mecánico, la solubilidad en agua caliente, en $\mathrm{NaOH}$ y Extractos Alcohol-Benceno. De la misma manera, se estudió el comportamiento de la brillantez en las pulpas mecánicas producidas a partir del bagazo almacenado. Sobre la base de los resultados obtenidos, se calculó para cada alternativa las pérdidas por almacenamiento y se demostró que el pre-secado de bagazo en comparación con los rendimientos de almacenamiento húmedo rinde menores pérdidas y una mejor conservación de sus características.

\section{Introduction}

Sugarcane bagasse is the fibrous residue of sugarcane (Saccharum officinarum) after the extraction of juice. Bagasse, as agro-based fibers, have the composition, properties and structure that make them suitable for uses such as composite, textiles, pulp and paper manufacture and animal feed, among others (Narendra and Yang, 2005). In addition, bagasse bio-fibers can also be used to produce fuel, chemicals, enzymes and food and is one of the most relevant sugarcane by-products of the cane sugar production industry, a mixture of hard fiber, with soft and smooth parenchymatous (pith) tissue, having high hygroscopicity, soil, wax, residual sugars, etc., remaining after the cane has been crushed and extracted the juice (Lois, 2009;
Galvez, 1994). Sugarcane bagasse consists of cellulose, 43.6\%, hemi-cellulose, 33.8\%, lignin, $18.1 \%$, ash, $2.3 \%$ and wax, $0.8 \%$, on a dry weight basis (Sun et al., 2004).

Other applications of sugar-cane bagasse are as sources of animal feed, energy, pulp and paper, furfural, polymers, and agglomerated boards, as well, which represent valuable raw materials for countless industries (Banerjee and Pandey, 2002). However, bagasse is still discarded in not very productive ways such as in the generation of energy for the sugar plant that processes the sugar cane, or returned inefficiently to the fields as fertilizer, or simply burnt, which results in 
irreparable harm to environment, directly tied to air pollution (Kirchhoff, 1991). Hence, bagasse is currently the primary fuel for sugar milling and processing operations, with occasional supplementation by sawdust, coal and fuel oil. Some mills produce more power from fuel burning equipment than is required for the sugar milling process. The excess power is sold and exported to the electricity grid. This process is called cogeneration (De Armas, 1994).

Due to the seasonal character of sugar industry, large amounts of bagasse should be stored for the operation of the plants during the off-season periods. Temperature rises in the stored bagasse and workmen often suffer from "bagassosis", an allergy response that may occur in susceptible individuals to the presence of bacterial spores (Thermoactinomyces sacchari) that can develop in stored bagasse. The allergic response affects the lungs and may cause breathing difficulties. Furthermore, the quality of products manufactured from rotten bagasse is diminished (Schmidt and Walter, 1978). Other organisms are cellulolytic and cause fiber deterioration of the bagasse stored (Rivacoba and Lois, 1982). Heating and contamination could be much decreased either by drying to about $25 \%$ water content, which halves the spore content after storage, mostly at the expense of the Actinomycetes, or by adding $2 \%$ by weight of the propionic acid, which decreases the spore content to $4 \times 10^{6}$ spores/g or less, even after 18 months storage (Lacey, 2008).

Several methods have been proposed to avoid these microbial activities. There exist different storage methods, and their choice depends mainly on the type of production. One of the most common methods used in the industry of bagasse fiber boards and few pulp and paper factories in all over the world since the 50s has been the bale compacted system (Atchison, 1977; Lois, 1994). When bagasse is baled and stored such as it comes out from the cane sugar mills $(48-52 \%$ humidity), it constitutes a rich substrate for the development of microorganisms (Lois, 1979). During the first days of storage, the temperature rises rapidly in the interior of the bales, which together with other conditions create fiber degradation processes, darkening, high fiber losses and other chemical-physical damages, as well (Lois, 1982; Schmidt and Walter, 1978).
An alternative in the baled storage method consists in drying the bagasse to bring down the humidity in the order of $20-25 \%$ before it is baled. This method considerably decreases the development of fermentation and, at the same time, it makes possible to produce bigger bales, higher storing capacities and reduce the fiber losses (Lois, 1982).

Despite the several published papers about the behavior of bagasse stored in bales (Lois and Suarez, 1983; Nakasone and Oda, 1976), there are not available evidences regarding enough reliable and accurate information upon the incidence of the different alternatives of this method on the quality of the stored material, and opinions about the figures of the storage losses are contradictory. During the last years, several studies and experimental works have been carried out by different institutions on the various alternatives of storage methods, among them that of bale storage method.

The objective of the present work was to determine the comparative influence of the storage time on the stored material, physicochemical changes, fiber losses and some other technological aspects.

\section{Experimental work}

In a zone adjoining "Pablo Noriega" sugar mill in the province of Havana, Cuba, three experimental piles of about 140 bagasse bales in each pile were erected with the following coding characteristics:

i. Wet raw bagasse "IN" ( 50\% M.C. $\left.{ }^{*}\right)$

ii. Wet depithed bagasse "DH" ( $50 \%$ M.C.)

iii. Pre-dried depithed bagasse "PR" ( 25\% M.C.)

In the case of "DH" bagasse, the depithing operation was carried out in horizontal rotor type depithers, "Horkels". In the case of "PR" bagasse the depithing was carried out in vertical rotor type depithers, "S.M. Caribe", and further pre-dried in flash type pneumatic dryers. The scheme of the experimental plan is shown in Fig.1.

In each case, the bagasse was sampled and characterized before baling, the moisture content was determined, sampled and characterized before baling too, and the moisture content was determined every 15 minutes. The initial characterization included particle size (granulometry) and morphological analysis, 


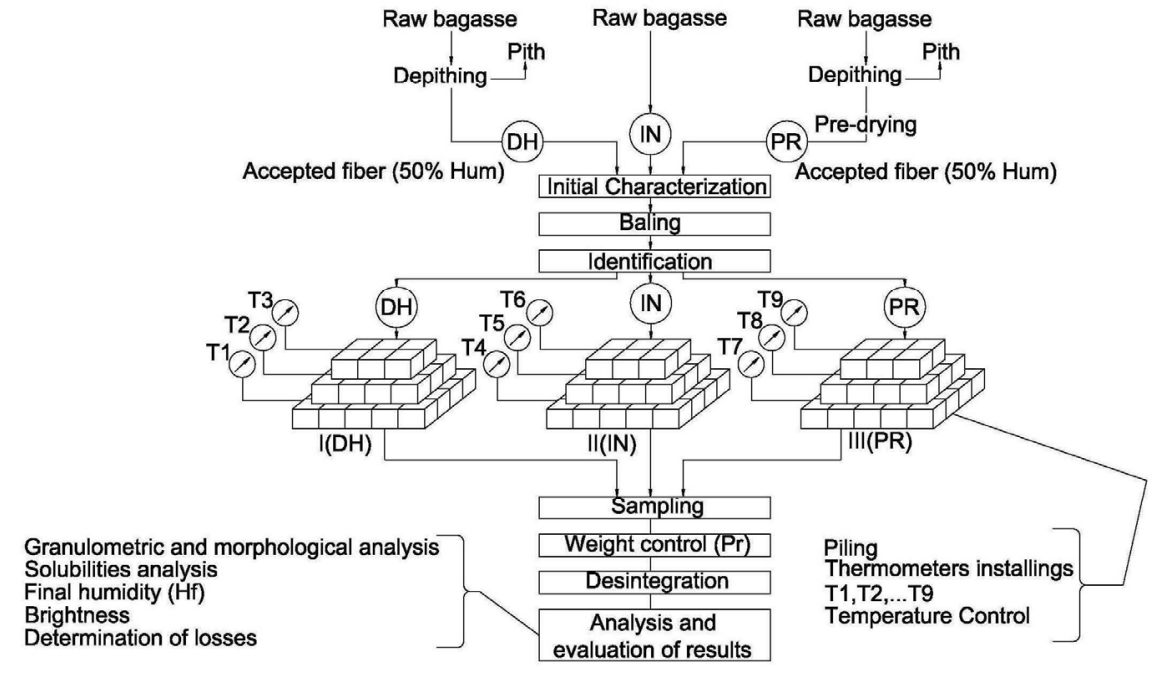

Figure 1. Experimental working plan.

cellulose, lignin and pentosans contents, solubility in hot water, $\mathrm{NaOH}(1.0 \%)$, alcohol benzene extractives and brightness degree of mechanical pulps, as well. In the cases of "IN" and "DH", the dimensions of bales were of $150 \times 80 \times 80 \mathrm{~cm}$ and $320 \mathrm{~kg}$ bone dry each, which is the standard size usually produced in the systems of wet baling in mechanical presses with manual wiring. In the cases of "PR", the bale volume was three times bigger in comparison with the other two cases and the baling was carried out in automatic wiring hydraulic presses. The bales were transported by trucks and normal lifting equipment was used for its handling and piling.

Before piling, 15 bales were sampled from each pile for a total of 45 which were measured, identified by means of metallic sheets and control in weight as well. In Table 1, the average values of the previous identified bales are shown.

\begin{tabular}{lrrrrrr}
\hline Parameter & \multicolumn{1}{c}{$\begin{array}{c}\text { Wet Raw } \\
\text { Bagasse (IN) } \\
\text { Average Std. Dev. }\end{array}$} & $\begin{array}{c}\text { Wet Depithed } \\
\text { Bagasse (DH) } \\
\text { Average Std. Dev. }\end{array}$ & $\begin{array}{c}\text { Pre-dried Depithed } \\
\text { Bagasse (PR) }\end{array}$ \\
Average Std. Dev.
\end{tabular}

Table 1. Average characteristics of bales. 
From data from Table 1, it is noted that the volume $\left(V_{0}\right)$ of pre-dried bagasse bales "PR" was 2-3 times higher than those of wet bagasse, i.e. raw "IN" and depithed "DH". On the other hand, the density $\left(\rho_{0}\right)$, of the wet baled depithed bagasse ("DH") and wet baled raw bagasse ("IN") was 1.1 and 2.3 times higher, respectively, than that of pre-dried baled depithed bagasse "PR". The initial moisture content of depithed bagasse "DH" (47,4\% M.C.) was lower than that of wet raw bagasse "IN" (52.0\% M.C.), probably as a result of the partial transformation of kinetic energy to thermal energy in the depithing mill without excluding the influence of pith removal upon the moisture content of bagasse.

The three experimental piles were erected at four levels in pyramid form and were covered with corrugated roofing tiles to protect the stored bagasse from the rain. Three thermometers were installed in the interior of each pile at different heights over the ground level in order to record the bagasse temperature behavior during storage time. In a period of time from April to September, the bales were randomly sampled and their final weight (Pf) was determined. Then, the bales were disintegrated as follows: in a clean area the sampled bagasse was placed upon a polyethylene mat sectioning it at half its volume and, afterwards, it was manually disintegrated in a careful and rapid way to decrease the possible humidity variations. Five samples of bagasse were taken from each pile, properly homogenized; then, they were packed in a polyethylene bag which was sealed and identified afterwards with a code.

The granulometry and morphological analyses were carried out:

1. With the samples of bagasse without being subjected to any mechanical treatment.

2. With the samples of bagasse after being processed in a pilot plant hammer mill.

The objective of this test was to compare the influence of storage time upon the sensitivity of the material to mechanical treatments, "degree of fragility", term usually employed in particle board industries. The possible increase of the "fine fraction" was also measured. The analytical modified techniques (ICIDCA) DP-1 and DP-2, with screens (mesh/mm): 1.0/25.4; 2.5/8.0; 10.0/1.68; $18.0 / 0.9205 ; \quad 30.0 / 0.547$ and $60 / 0.25$ were respectively used to carry out the morphological and granulometry analysis. The sum of the fractions passing the mesh 18.0 was denominated "fine fraction".

The indexes of losses due to storage were determined on the basis of the differences between the initial and final dry basis weight of the sampled bagasse bales. Traditional worldwide known techniques were used for the rest of the analysis.

\section{Results and discussion}

\subsection{Temperature and humidity records of bagasse}

The temperature values in the interior of the bales were recorded every three hours during three months. In Fig. 2, the daily averages measurements are shown. The values of ambient temperature as it was reported out by the National Meteorology Institute in the zone of the experimental area are also included for comparison. From the obtained results, it was possible to make the following comments:

1. In the cases of both wet baled bagasse ("IN" and "DH"), the maximum temperature rise was recorded in the first week of storage, reaching values of $60-65{ }^{\circ} \mathrm{C}$ and even occasionally higher. From that moment, the temperature began to decrease down to about $30^{\circ} \mathrm{C}$ after 6 - 7 weeks of storage.

2. In the case of wet baled depithed bagasse ("DH"), higher temperature values were recorded perhaps due to a higher bale densification.

3. In the case of pre-dried baled bagasse ("PR"), there was a slight rise in temperature during the first 2-3 days reaching $50{ }^{\circ} \mathrm{C}$. From that moment on, the temperature decreased rapidly reaching 30 ${ }^{\circ} \mathrm{C}$ after 10 days of storage keeping in that range.

4. The temperature values recorded in the case of both wet baled bagasse ("IN" and "DH") showed an intense exothermic microbiological process while in the case of pre-dried baled bagasse "PR" this process was lower due to its low humidity. The results of humidity determinations are graphically shown in Fig. 3. 


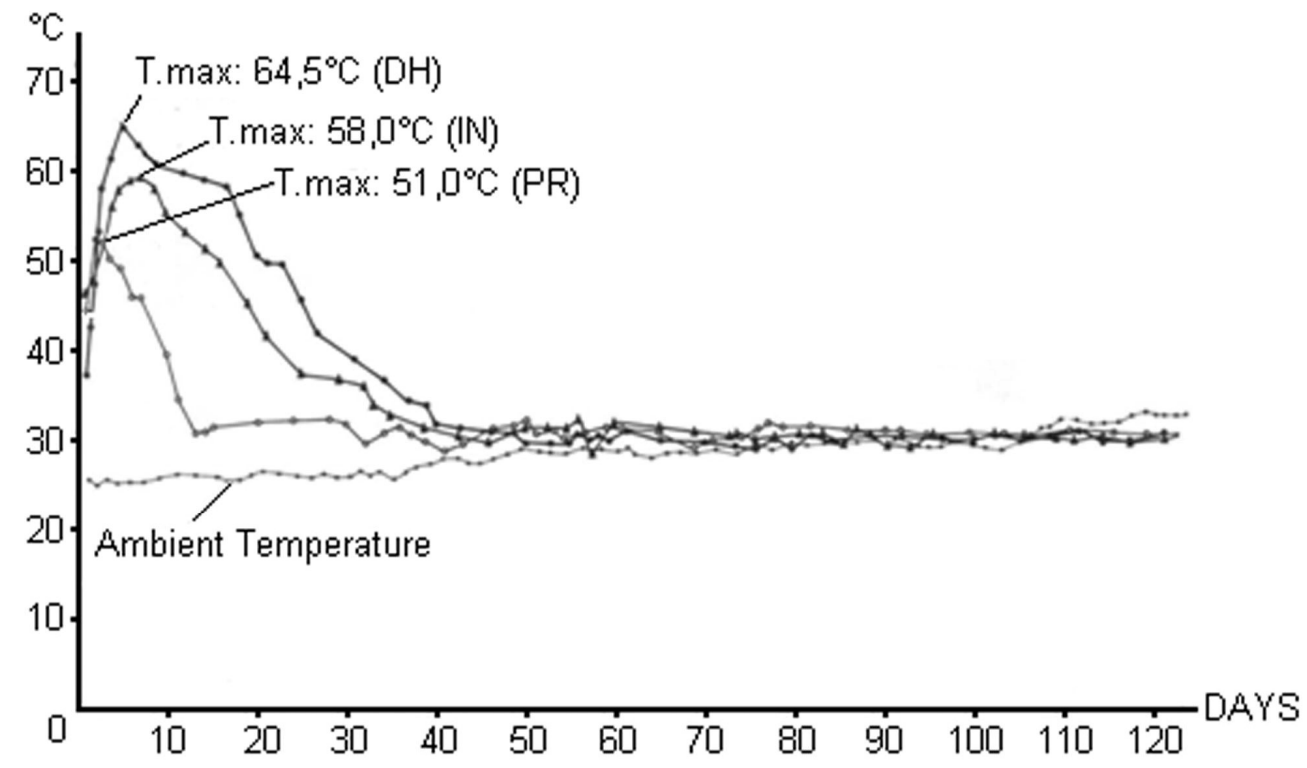

Figure 2. Average bagasse temperature vs. storage time. $\mathbf{\Delta}$ Wet raw bagasse;

- Wet depithed bagasse; OPre-dried depithed bagasse.

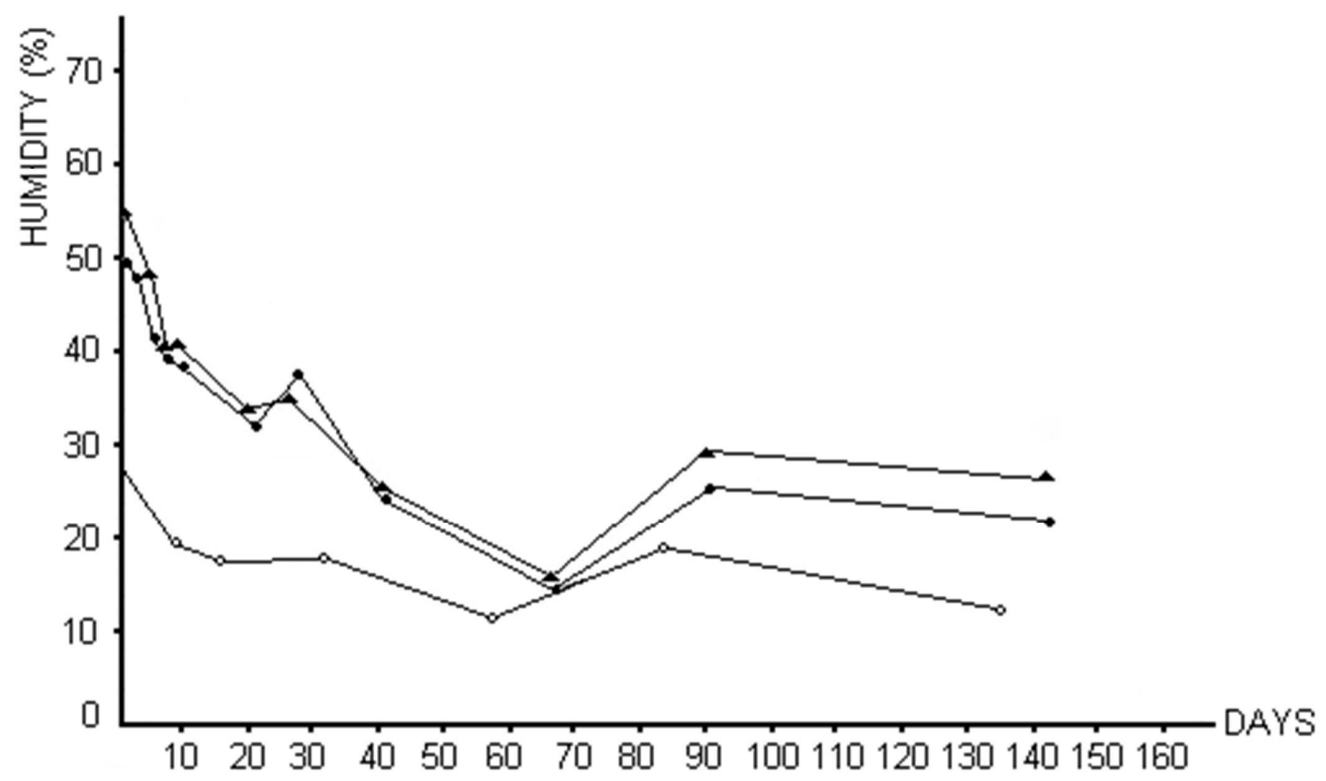

Figure 3. Humidity vs. storage time. $\boldsymbol{\Delta}$ Wet raw bagasse;

Wet depithed bagasse; OPre-dried depithed bagasse. 


\section{Experimental Evaluation of Sugar Cane Bagasse Storage in Bales System, J. Lois-Correa et al., 365-377}

As it was expected, it can be seen from the obtained results that the humidity values decreased as temperature arose. The highest decrease was observed during the first week of storage. In the case of wet baled bagasse ("IN" and "DH"), the initial humidity decreased from circa $50 \%$ to $35 \%$ in the first week, and after 6-7 weeks, a value of $15 \%$ was reached.

The humidity of the pre-dried baled bagasse ("PR") decreased similarly from an initial value of $25 \%$ to $15 \%$ in an equal period. The observed humidity variations can be mainly due to changes in ambient humidity registered in the rain season of the year in the zone where the experiments were carried out.

\subsection{Determination of Storage Losses}

The behavior of the losses in terms of the storage time for each one of the three cases ("IN", "DH" and "PR") is graphically shown in Fig. 4.

The experimental values were fitted with the aid of a program that determines the best regression line which passes through the origin of coordinates to correspond with the physical fact that in "time zero" the losses do not exist.

Analyzing the results and taking into account that determinations were only carried out on the basis of both dry initial and final weights $\left(P_{0}\right)$, it can be noted that

1. The higher losses were observed in the cases of both wet baled bagasse, "IN" and "DH", during the first 6-7 weeks of storage. After 40 days, some stabilization was observed in a $20-25 \%$ range of losses.

2. In the case of wet baled depithed bagasse, "DH", losses were slightly lower if compared with wet baled raw bagasse, "IN", thus indicating better conservation degree.

3. In the case of pre-dried baled bagasse, "PR", the increase of losses was slower during the storage time reaching a top value of $6.5 \%$ after four months of storing.

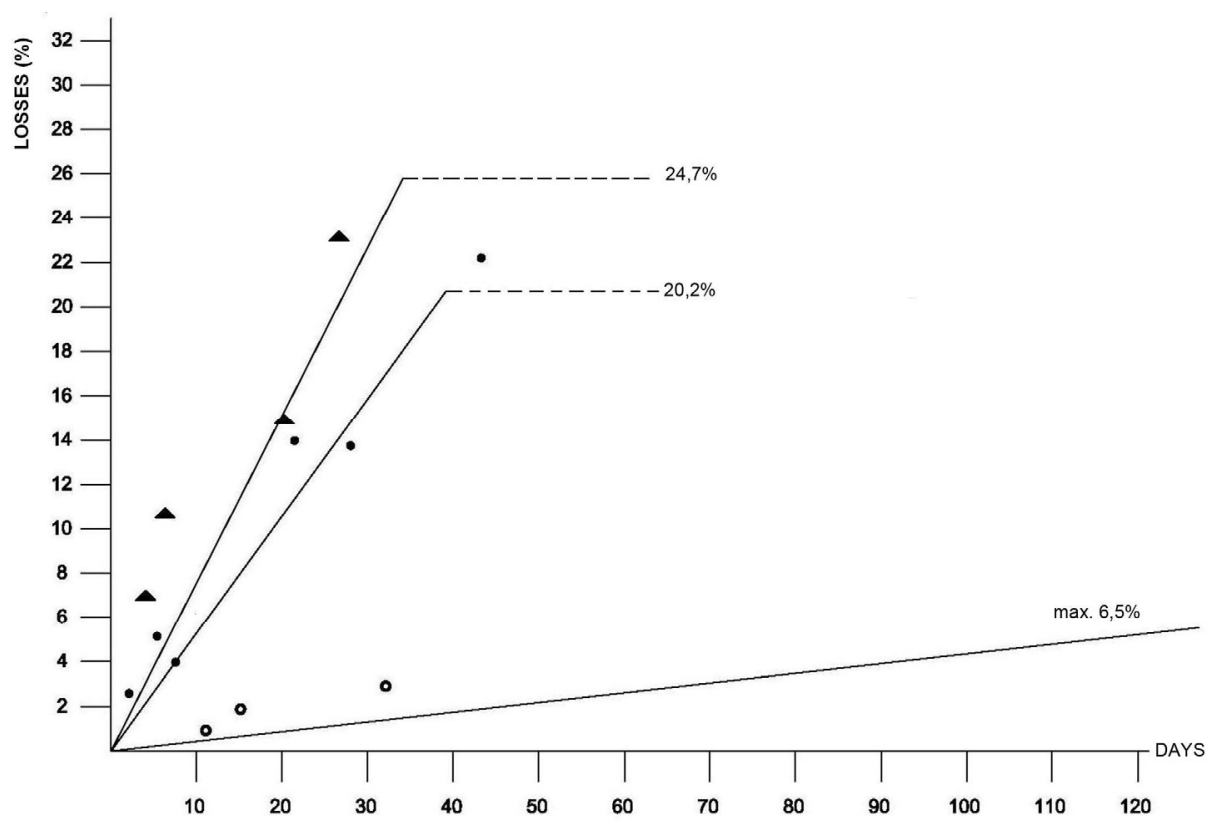

Figure 4. Dry fiber losses vs. storage time. $\mathbf{\Delta}$ Wet raw bagasse;

Wet depithed bagasse; OPre-dried depithed bagasse. 
The obtained results showed that wet baled bagasse is submitted to intense chemical and microbiological processes and to an enzymatic destruction in the initial stage of its storing. With the pre-drying of bagasse, the conservation degree of the material is much higher.

\subsection{Granulometrical and Morphological Analysis}

In the case of bagasse before milling in a hammer mill, the attempt to correlate the percent of "fine fraction" (total passing mesh 18) with storage time did not give satisfactory results.

However, it could be observed that in all cases, obtained average values are always higher than the initial value. In the case of milled bagasse, a significant correlation was not found between the percent of "fine fraction" and storage time either.

A comparison for each type of bagasse regarding the content of fines in non milled and milled material is shown in Table 2 . The values are only analyzed at the beginning and the average of the rest of measures.

From the obtained results, it is difficult to draw conclusions regarding the influence of storage time on the sensitivity of the material to milling processes. This can be due to sampling errors, typical inaccuracies of the granulometrical techniques and possibly to a very intensive milling process which filled the differences in the "fragility degree" of the material. In the results of the morphological analysis for bagasse before milling, in general, no significant correlation was found between the percentage of fiber and the storage time.

In the case of milled bagasse, it was demonstrated that there exists a decreasing tendency of fibers percentage in the cases of wet baled bagasse ("IN" and " $\mathrm{DH}$ ") of about $10 \%$ and $8 \%$, respectively after 4-5 months of storage time. In the case of pre-dried baled bagasse ("PR"), no significant correlation was found.

In Figures 5 and 6, where the experimental values and the regression curves have been plotted for the cases "IN" and "DH", it can be noted that as the storage time increases, the differences between the percentage of bagasse fiber before milling and milled increases too.

Bearing in mind that the morphological analyses are more accurate than the granulometrical ones, it can be stated that the results show some increases of the "fragility degree" of stored bagasse by the system of wet bales.

\begin{tabular}{lcccrrr}
\hline Type of bagasse & \multicolumn{2}{c}{$\begin{array}{c}\text { Wet Raw } \\
\text { Bagasse (IN) } \\
\text { Initial }\end{array}$} & $\begin{array}{l}\text { Wvet Depithed } \\
\text { Avagasse (DH) } \\
\text { Initial Average }\end{array}$ & \multicolumn{2}{c}{$\begin{array}{c}\text { Pre-dried Depithed } \\
\text { Bagasse (PR) } \\
\text { Initial Average }\end{array}$} \\
\hline Before milling & 32.07 & 34.74 & 24.03 & 25.46 & 4.65 & 12.87 \\
Milled & 55.22 & 56.78 & 48.10 & 51.10 & 44.50 & 33.99 \\
Difference & 23.15 & 22.04 & 24.07 & 25.64 & 39.85 & 21.12 \\
\hline
\end{tabular}

Table 2. Influence of milling process on the "Fine Fraction" (passing mesh 18), \%. 


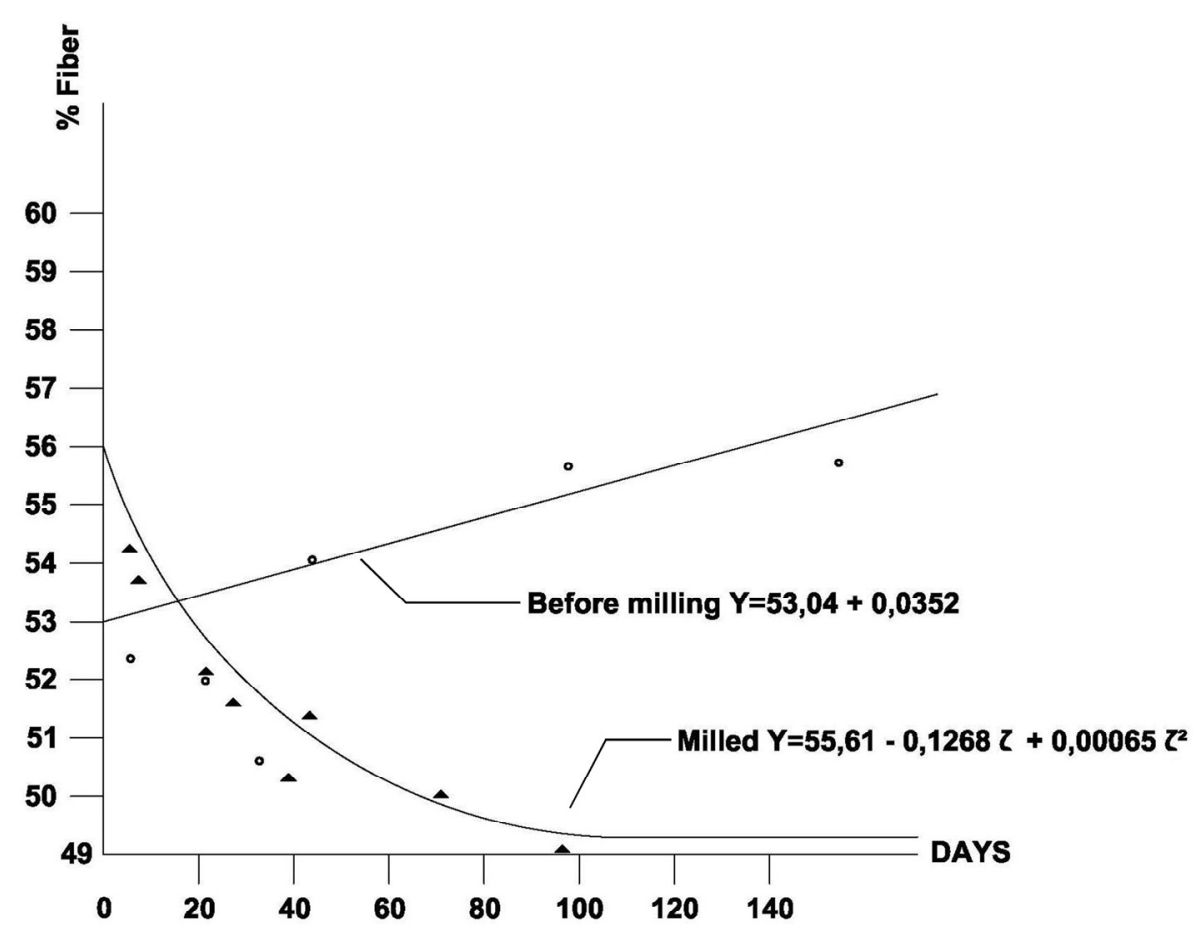

Figure 5. Fiber content of wet raw stored bagasse (IN).

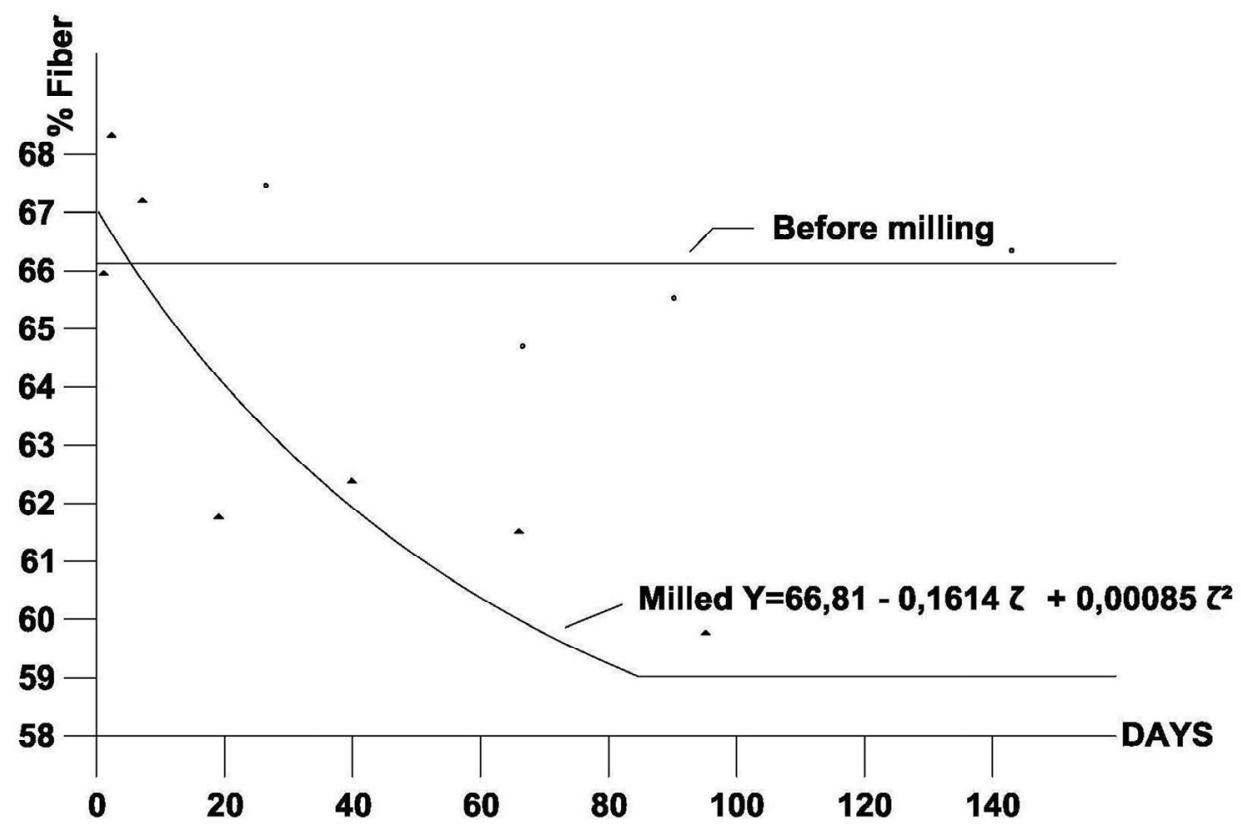

Figure 6. Fiber content of wet depithed stored bagasse. 
3.4. Analysis of Solubility and Alcohol - Benzene Extractives

The results of the analyses for the three analyzed alternatives are shown in Table 3.

From their analyses, it can be observed that

a. The soluble content in hot water decreased by $60-65 \%$ approximately and $40-45 \%$ of its initial value, respectively, for the wet bales bagasse "IN" and " $\mathrm{DH}$ ".

b. On the other hand, the soluble content in $1.0 \%$ $\mathrm{NaOH}$ decreased $15-20 \%$, respectively, for the "IN" and "DH" cases. In the case of "PR", the decrease was of $7-10 \%$.

c. The extractives in alcohol-benzene decreased approximately 30-35\% (“IN"), 15-20\% (“DH") and $20 \%$ ("PR").

\subsection{Brightness Analysis}

Mechanical pulp sheets were made for each of the types of bagasse for determining the influence of bagasse quality upon brightness. The results, obtained with a Datacolor ELREPHO designed specifically for the use of the paper industry, are shown in Fig. 7 where the difference between the initial brightness values and the fact that the depithing operation notably influences on this parameter can be observed.

Regarding the brightness behavior during storage, it should be noted that in the cases of mechanical pulp sheets from wet baled bagasse ("IN" and "DH"), a marked decrease is noted with few differences. In the case of pre-dried depithed bagasse ("PR"), no significant change was observed.

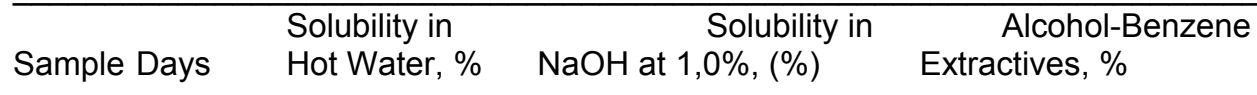

\begin{tabular}{|c|c|c|c|c|}
\hline & & & & \\
\hline $\mathrm{IN}-0$ & --- & 5.07 & 38.43 & 4.48 \\
\hline $\mathrm{IN}-1$ & 4 & 4.47 & 32.10 & ---- \\
\hline $\mathrm{IN}-2$ & 6 & 3.37 & 28.25 & 2.54 \\
\hline IN-4 & 19 & 3.76 & 24.11 & 3.34 \\
\hline IN-6 & 39 & 2.77 & 25.01 & ---- \\
\hline IN-8 & 89 & 3.71 & 26.34 & 2.28 \\
\hline IN-9 & 141 & 1.72 & 26.10 & 2.88 \\
\hline & & & & \\
\hline $\mathrm{DH}-0$ & --- & 4.75 & 34.35 & 6.42 \\
\hline DH-1 & 2 & 3.31 & 32.58 & ---- \\
\hline $\mathrm{DH}-2$ & 5 & 6.12 & 31.06 & 3.81 \\
\hline DH-3 & 7 & 3.58 & 31.40 & ---- \\
\hline DH-5 & 20 & 2.76 & ---- & 3.20 \\
\hline DH-6 & 40 & 3.58 & 26.94 & ---- \\
\hline DH-7 & 90 & 2.42 & 25.72 & ---- \\
\hline $\mathrm{DH}-8$ & 142 & ---- & 28.15 & 6.23 \\
\hline & & & & \\
\hline PR-0 & --- & 10.40 & 36.89 & 8.32 \\
\hline PR-2 & 14 & 10.65 & 34.51 & 10.13 \\
\hline PR-3 & 30 & 5.36 & 34.35 & ---- \\
\hline PR-5 & 82 & 9.54 & 34.16 & ---- \\
\hline PR-6 & 134 & 6.45 & 34.03 & 5.90 \\
\hline
\end{tabular}

Table 3. Solubility of stored bagasse referred to initial weight. 


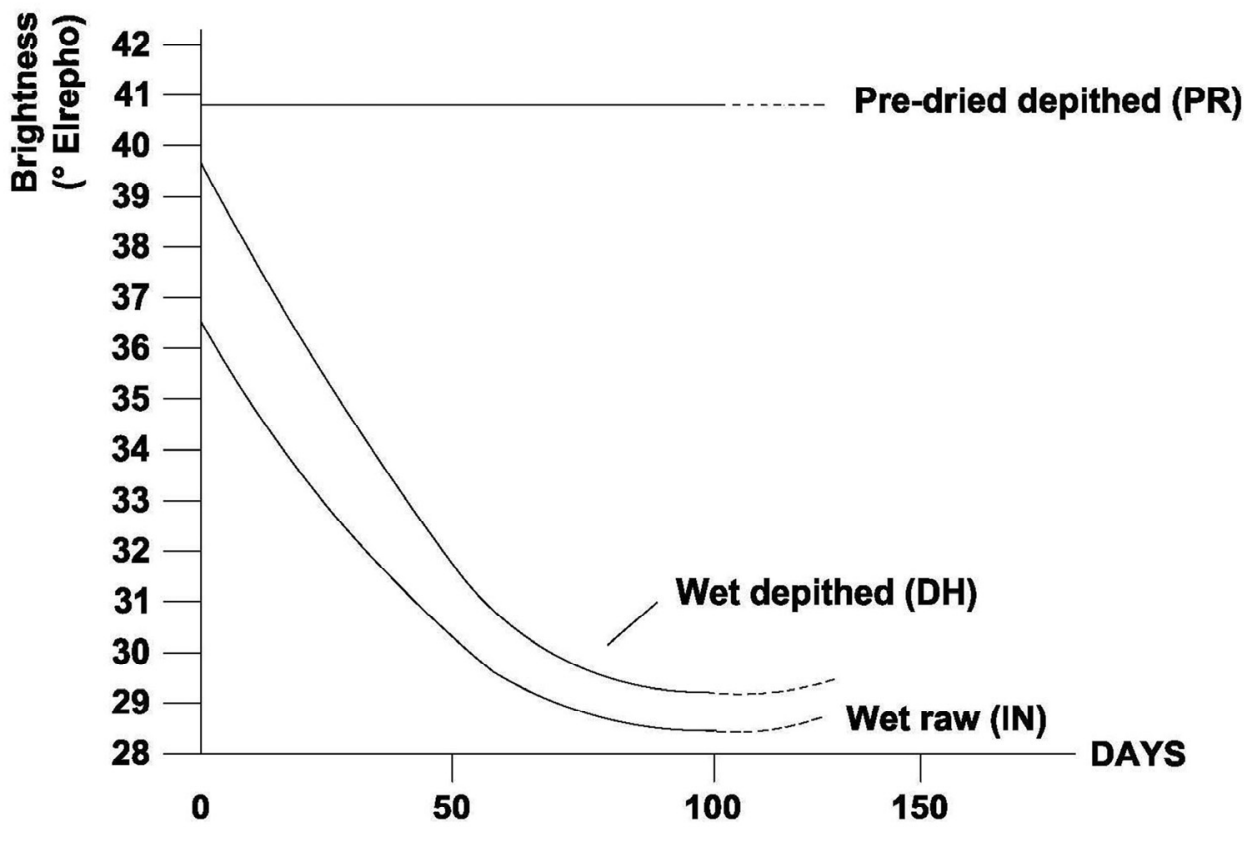

Figure 7. Degree of brightness vs. storage time.

\section{Conclusions}

From the results of the evaluated experimental work, it can be stated that both wet baled stored bagasse, raw "IN" and depithed "DH", show a greater deterioration and changes than in the case of pre-dried baled ("PR") stored bagasse. As an important aspect which backs up this conclusion, it can be pointed out for cases "IN" and "DH" that

1. The temperature profile makes evident an intense temperature rise in the first eight days of storage reaching values of up to $65^{\prime} \mathrm{C}$ in the case of wet baled bagasse "IN" and "DH" followed by a gradual decline until values of around $30{ }^{\circ} \mathrm{C}$ were reached in 40 to 50 days, remaining constant for the remainder storage time.

2. An increase of the difference between the percentage of bagasse fiber before milling and after milling was reported and this may constitute an index of the "fragility degree" of the material.

3. As a result of microbiological activity, the fiber losses due to storage are significant for wet baled bagasse and it can be stated that they are above values of $20 \%$.

4. In the chemical analysis, a decrease of the cellulose and pentosans content and no significant change of the lignin content were observed.

5. The soluble content in hot water exhibited a marked tendency to decrease in dependence of the storage time.

6. The brightness of wet baled bagasse is seriously affected and only few differences are noted between each case.

7. Evidence that depithing operation introduces significant variations in this examined aspect was not observed.

8. In the case of pre-dried stored depithed bagasse "PR", a higher conservation was observed characterized by the following facts:

- Losses due to storage are sensitively lower with figures ranging between 4.0 to $6.0 \%$. 
- Reduced temperature rise making evident less microbiological activity.

- Significant changes are not observed in the granulometrical, morphological and in the chemical analyses, as well.

- Brightness of bagasse did not show a significant correlation with storage time.

\section{References}

[1] Narendra, R. and Y. Yang. Biofibers from agricultural byproducts for industrial applications. Trends in Biotechnology, 2005, Volume 23, Issue 1, January, pp.22-27

[2] Lois, J. Sugar cane and co-products. Proceedings of XXXII ATAM Convention, 2009, Cordoba, Veracruz, August.

[3] Galvez, L. The Development of Sugar Cane ByProducts in Cuba, 1st International ISSCT Workshop on Sugar Cane By-Products, 1994, pp. 23-38, Havana, Cuba, March.

[4] Banerjee, R. and Pandey, A. Bio-industrial application of sugarcane bagasse: a technology perspective, 2002, Int. Sugar Journal, 1, pp.3-7.

[5] Kirchhoff, V. W. J. H. As queimadas da cana. São José dos Campos: Transtec Editorial. IN: Sustainability: use of sugarcane bagasse and bamboo leaves to produce sealing boards, 1991, POMS 20th Annual Conference Orlando, Florida U.S.A. May 1 to May 4, 2009.

[6] De Armas, C. Comments about co-generation in the sugar industry. Proceedings of International Seminar on Commercial Energy Generation in the Cane Agroindustry, 1994, GEPLACEA, ASAZGUA and GTZ. Guatemala, June.

[7] Schmidt, O. and Walter, K., Sucession and Activity of Microorganisms in Stored Bagasse, European J. Appl. Microbiology and Biotechnology, Springer-Verlag, 1978, pp. 69-77, Berlin, Germany.

[8] Lois, J., Storage of Bagasse for Derivatives Industries, Monograph, Editorial Científico-Técnica, 1982, pp. 13-27, Havana, Cuba (in spanish).
[9] Lacey, J. Moulding of sugar cane bagasse. Annals of applied biology, 2008, Volume 76, Issue 1 pp 63-76.

[10] Atchison, J.E., Making Bagasse Available, XVI Congress of ISSCT, 1977, pp. 54-66, South Africa.

[11] Lois, J. Bagasse Storage for Industrial Use, International Seminar on Commercial Energy Generation in the Cane Agroindustry GEPLACEA, ASAZGUA and GTZ, 1994, Guatemala City, Guatemala, April.

[12] Lois, J. et al, Experimental Evaluation of Bagasse Stored in Wet Bales in the Bagasse Boards Factory PROCUBA, 43 rd Congress of Cuban Association of Sugar Technicians ATAC, 1979, Havana, Cuba (in spanish).

[13] Lois, J. Storage of Bagasse for its Industrial Utilization in Cuba, Ph.D. Thesis, 1982, University of Zvolen, Slovaquia.

[14] Lois, J. and Suarez, R., Experimental Evaluation of Bagasse Storage in Bale System, XVIII Congress ISSCT, 1983, pp. Havana, Cuba.

[15] Nakasone, H. and Oda, K., Studies on Bagasse Storage. Deterioration of bagasse particle boards, Wood Ind. 31 (3), 1976. pp. 104-107. 


\section{Authors' Biographies}

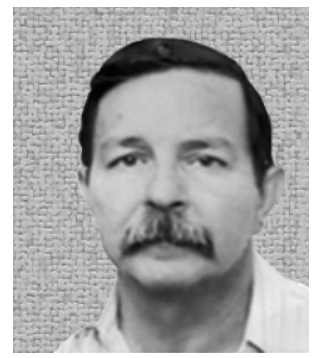

\section{Jorge Aurelio LOIS-CORREA}

$\mathrm{He}$ is a mechanical engineering graduated of the National Polytechnic University in Odessa, Ukraine. He obtained his Ph.D. degree in 1982 from the Forest and Wood Higher Studies School in Zvolen, former Czechoslovakia. From 1966 to 1968, he was the Head of the Project Division at the Cuban Research Institute of Sugar Cane By-products (ICIDCA) on R+D+I, related to sugar cane co-products. From 1997 to 2000, he worked as consultant in research and teaching at the Central University of Cauca's Valley UCEVA, in Colombia. For over 10 years, he was international co-products commissioner at the prestigious ISSCT (International Society of Sugar Cane Technologists). He has received several awards and special honors. Since 2000, he has been working as researcher-professor at the Research Center for Applied Science and Advanced Technology, CICATA-IPN, Tamaulipas, Mexico. Dr. Lois is author of 2 books and co-author of 4 . He has mentored 19 undergraduate students, $5 \mathrm{M}$.Sc. students and a doctorate student. He is author of 4 patents as well. He is author of 45 scientific articles and 50 papers in congresses and other academic events and has served as a referee for several international publications. Besides, he has given various lectures by invitation and has provided technical assistance in 13 countries.

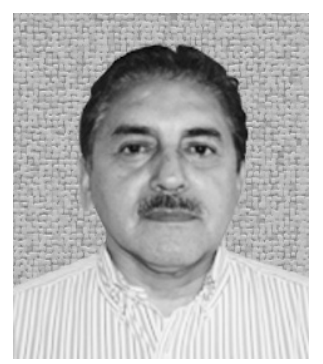

\section{Abelardo Irineo FLORES-VELA}

$\mathrm{He}$ is a chemical engineering graduated of the Benemérita Universidad Autónoma de Puebla, México. He obtained his Ph.D. degree in 1988 at the Center for Research and Advanced Studies of Instituto Politécnico Nacional (CICATA-IPN), Tamaulipas, Mexico. From 1983 to 2001, he worked at Instituto Politécnico Nacional as researcher-professor. From 1990 to 1992, he was researcher (he focused his research on $\mathrm{R}+\mathrm{D}+\mathrm{I}$ related to synthesis of coatings polymers) at the Polymer Research Center, Mexico. From 1995 to 1999, he worked as a technical support manager on coating, adhesive, paper board, pigments and carpet Polymers at BASF Mexicana. Also, at BASF Mexicana, he worked as quality control and special projects expertise from 1999 to 2003. Since 2004, he has worked as research-professor at the Research Center for Applied Science and Advanced Technology (CICATAIPN), Tamaulipas, Mexico. Since 2008, he has been technological innovation manager and since 2009 he has been director of CICATA-IPN. He is coauthor of 2 books. He has 12 international publications. Finally, he has 17 Bachelor thesis and 12 M.Sc. and more than 61 papers in Congresses and events. 


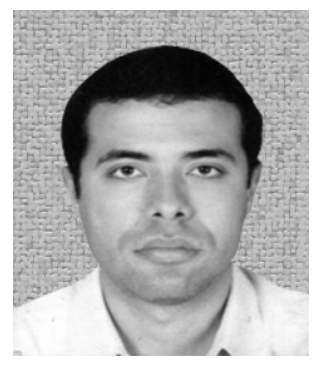

\section{Josue Benito BERMAN-DELGADO}

He graduated as a computer technician from Center for Technological and Industrial Services Studies in 2000 and as a chemical process engineer from the Instituto Tecnológico de Ciudad Madero, Tamaulipas, Mexico, in 2006. He completed his internship at the control laboratory of refinery "Francisco I. Madero" of PEMEX as a tester and analyst gas chromatography. He also worked as technical assistant in the Quality Control Department, CYEMSA. Currently, he is pursuing a master's degree in advanced technology at the CICATA-IPN (Altamira); his current research is focused on the development of molasses bio-cereals from the integral use of sugarcane and its co-products. He has attended several conferences as a speaker.

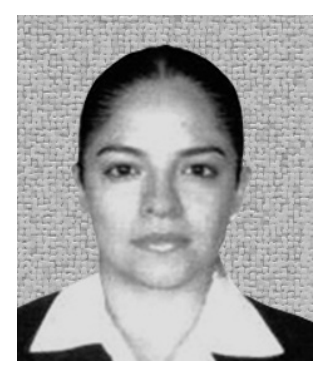

\section{Denisse Paola ORTEGA-GRIMALDO}

She graduated as a chemical laboratory technician from Industrial Technology Center and Services in 2001 and as a chemical environmental engineer from Instituto Tecnológico de Ciudad Madero, Tamaulipas, in 2006. She completed her internship in the Ecology Department of Ciudad Madero with the project "Environmental Operational Management System in Noise." She was responsible for an environmental education campaign at elementary education schools, among other environmental management activities. She worked for the prevention and control in the processing area at the company SIMCO, Inc. de CV, from December 2006 to April 2007 in the Engineering and Instrumentation Equipment Sales Department. She is currently pursuing a master's degree in advanced technology at the CICATA-IPN (Altamira), Tamaulipas; her research is focused on developing animal feed meals based on the integral conversion of sugarcane, including its whole biomass. She has attended several congresses as a speaker. 